\title{
Holistic Pedagogy and Early Childhood Education Good Shepherd Kindergarten - St. Stanislav's Institution in Ljubljana
}

Špela Avšič

spela.avsic@stanislav.si

Tadej Rifel**

adej.rifel@stanislav.si
UDK: $37: 282$

373.2:282(497.4)

Pregledni članak / Review

Primljeno: 17. kolovoza 2016. Prihvaćeno: 1. listopada 2016.

The first part of the article presents the basic characteristics of holistic pedagogy. First, it highlights its principles and fundamental premise, placing the human being as a person in the centre of attention. It thus establishes a theoretical framework for further discussion on teaching practices in early childhood education. Later, the authors focus on the experience of holistic pedagogy in Catholic schools. They point out the key aspects that interconnect the innovations of holistic learning environments and the values of Catholic schools. Special emphasis is put on creativity. In the second part, the principles of holistic pedagogy are illustrated by the example of the Good Shepherd Kindergarten, which operates within St. Stanislav's Institution in Ljubljana. This private Catholic kindergarten confirms and develops holistic approaches to early childhood education in multiple areas.

Keywords: Holistic pedagogy, early childhood education, Catholic schools, creativity, teaching practice.

\footnotetext{
* Špela Avšič. Headmistress of the Good Shepherd Kindergarten, St. Stanislav's Institution, Štula 23, 1210 Ljubljana Šentvid, Slovenia.

**Tadej Rifel, PhD. Independent Researcher at the Institute for Education Research and Development, St. Stanislav's Institution, Štula 23, 1210 Ljubljana Šentvid, Slovenia.
} 


\section{Introduction}

Interest in the human being is central to holistic pedagogy. Every individual as a person has inalienable dignity. The holistic understanding of education is aimed at developing the intellectual, emotional, social, and physical aspects of individual personalities. Human beings are by nature symbolic creatures. ${ }^{1}$ This implies, inter alia, that they are able to be creative, to search for meaning, and to outperform themselves. An educational institution that adheres to the principles of holistic pedagogy is a place of dialogue among science, arts and faith. ${ }^{2}$ The potentials of holistic human beings can best be developed in an appropriate holistic environment, i.e. in a community involving other persons. The common project of upbringing thus includes parents, teachers, and children/ students themselves. At the same time, the school community itself represents a kind of unique coexistence in diversity. In the process of creating a culture of community, every individual contributes his or her uniqueness and co-builds a coherent whole. The persons responsible for educational processes put constant effort in maintaining an environment that fosters mutual understanding, friendship, and solidarity. The main educational stakeholders, i.e. teachers, create a welcoming atmosphere and favourable climate for learning and holistic development. Below we will demonstrate how all this is reflected in the Good Shepherd Kindergarten, which operates within St. Stanislav's Institution.

\section{The Premise and Principles of Holistic Pedagogy}

The holistic aspect of pedagogy is best reflected in the fact that the child and his or her specific life story come first. The child is the true promoter of holism in the reality of his or her existence. The programmes, approaches, methods, and other aspects of pedagogical processes are only the secondary indicators of diversity and multiplicity. "Holistic education is starting with me. And holistic education means understanding that everything is interconnected and that I am the expert and that I am made up of body, mind spirit, and emotions." ${ }^{3} \mathrm{Ho}-$ listic education is thus often associated with alternative pedagogical theories, which do not want to be infiltrated into the general educational system, or

${ }^{1}$ Cf. e.g. Anton TRSTENJAK, Človek simbolično bitje, Ljubljana, Mladinska knjiga, 1996.

2 See Roman GLOBOKAR, Tone ČESEN (ed.), Šola kot prostor dialoga med vero, znanostjo in umetnostjo. Zbornik mednarodnega simpozija ob dvajsetletnici ponovnega delovanja Škofijske klasične gimnazije v Zavodu sv. Stanislava, 9. do 12. maj 2013 (= School as a Place of Dialogue Among Faith, Science and Arts. Proceedings of the International Symposium in St. Stanislav's Institution, $9^{\text {th }}$ to $12^{\text {th }}$ May 2013), collection: Simpoziji v Zavodu sv. Stanislava (= Symposia at St. Stanislav's Institution), 7, Ljubljana, Zavod sv. Stanislava 2013.

${ }^{3}$ Carlo RICCI, Conrad P. PRITSCHER, Holistic Pedagogy. The Self and Quality Willed Learning. New York et al., Springer 2015, 118. 
with the tendency to bring more openness to spiritual human issues in pedagogical processes. ${ }^{4}$ The schools established by religious communities, such as the Catholic Church, are therefore in many ways inspired by the principles of holistic pedagogy and often fully put them into practice.

It is interesting that, although based on human nature, the principles of holistic pedagogy do not search for their ideals only in the past, when educational institutions played a far more important role in the cultural development of humanity than today. ${ }^{5}$ As a rule, holism is understood as the implementation of possibilities in the future. The focus is on the developed personality that may force certain changes in society and culture. The issue of identity is always associated with the person a child or an adolescent becomes when growing into an adult. It is a dynamic process of evolving and moving towards the ideally set objective. From the perspective of holistic pedagogy, this ideal is, as mentioned before, always understood in an anthropological sense. In fact, it is about finding oneself and achieving everything that is most worthy of humans. This is how human beings outperform themselves.

Above we mentioned the following principles of holistic pedagogy: care for individual's holistic development, dialogic structure of educational processes, importance of community, stimulating environment, deriving from oneself, and search for added human value. Finally, we referred to the issue of personal identity. Human beings are creatures that constantly make themselves relevant. In other words, they are continuously evolving and changing. Therefore, it is necessary to highlight the final principle, i.e. the importance of vitality that helps holistic pedagogy to maintain contact with the environment in which it takes place. This environment can be traditional or modern; it only matters that it constantly allows individuals to make themselves relevant through dynamic relationships with other or different individuals. Moreover, as mentioned at the beginning, the symbolic dimension of human existence reflects an essential component of relationality. This is also increasingly confirmed by modern pedagogical sciences. ${ }^{6}$ The understanding of the fact that holistic pedagogy is mostly about developing children's inner potential best sums up the principles mentioned above.

\footnotetext{
${ }^{4}$ Cf. e.g. John P. MILLER et al. (ed.), Holistic Learning and Spirituality in Education. Breaking New Ground. New York, State University Press 2005.

${ }^{5}$ See the monumental work on education in antiquity, Henri Irénéé MARROU, Histoire de léducation dans l'antiquité. Paris: Éditions du Seuil 1965. Partial Slovenian translation (chapters on the Christian era) in: Tadej RIFEL, Marko WEILGUNY (ed.), Onkraj klasične šolske ustanove (Histoire de l'education dans l'Antiquité [selection]. The future of thinking [selection]). Collection: Katoliško šolstvo 3. Ljubljana, Inštitut za raziskovanje in evalvacijo šolstva 2015, $23-55$.

${ }^{6}$ See Robi KROFLIČ, Eros and Education, Šolsko polje. Revija za teorijo in raziskave vzgoje in izobraževanja, 14 (2003) 3/4, 33-52; and Eugene MATUSOV, Journey into Dialogic Pedagogy, New York, Nova Science Publishers, 2009.
} 


\section{The Value of Holistic Pedagogy to Catholic Schools}

As demonstrated in another work, ${ }^{7}$ learning environments in terms of holistic pedagogy place particular emphasis on the following innovation-supportive aspects:

- experience-based learning;

- learning in and for the community;

- strong emphasis on motivating students to acquire new knowledge and competence;

- deviation from traditional teaching practices;

- making space for creativity and innovation;

- integration between schools and other public and private institutions;

- promoting the informal assessment of achievements;

- careful planning and evaluation of learning environments.

Slovenian Catholic schools ${ }^{8}$ represent a place where the above-mentioned emphases are put into practice. In general, the basic mission of Catholic schools is to establish an educational framework that is closely connected with the experience of life. It would thus be very interesting to compare the abovementioned emphases with the so-called hallmarks of Catholic schools, such as:

- respect for individual dignity and uniqueness (hence the rejection of mass education and teaching, which make human beings easier to manipulate by reducing them to a number);

- a wealth of opportunities that are offered to young people for them to grow and develop their abilities and talents;

- a balanced focus on cognitive, affective, social, professional, ethical and spiritual aspects;

- encouragement for every pupil to develop their talents, in a climate of cooperation and solidarity;

\footnotetext{
7 Tadej RIFEL, Inovativno učno okolje z vidika celostne vzgoje. In: Eva VALANT (ed.), Udejanjanje inovativnih učnih okolij kot izziv vrtcev, šol in izobraževalnega sistema. Zbornik povzetkov V. znanstveni posvet Vodenje v vzgoji in izobraževanju. Portorož, 5. in 6. april 2016. Ljubljana, Šola za ravnatelje, 2016, 30-31.

${ }^{8}$ If considering all education levels, Slovenian Catholic schools are as follows: 20 kindergartens, 2 primary schools, 4 grammar schools with associated student dormitories, 5 music schools, 11 university student dormitories, and 1 faculty. More detail on individual institutions can be found on the new website of Slovenian Catholic schools: http://solstvo.rkc.si/ (12 July 2016).
} 
- the promotion of research as a rigorous commitment towards truth, being aware that human knowledge has its limits, but also with a great openness of mind and heart;

- respect of ideas, openness to dialogue, the ability to interact and work together in a spirit of freedom and care. ${ }^{9}$

The emphases of innovative learning environments seem to be interconnected with the values of Catholic schools. They both include what really matters in the world of pedagogy, i.e. putting the principles in teaching practice. In addition to the learning environment, it is necessary to consider teachers as the promoters of educational processes. Cooperation between schools and with other educational institutions in Slovenia and abroad also represents an important aspect, the plurality of approaches contributing to the success in providing mutual benefit for both children and society. There are many activities that confirm these interconnected aspects at the practical level.

The hallmark of "a wealth of opportunities that are offered to young people for them to grow and develop their abilities and talents" is the central point putting the human being as a person in the centre of attention. The development of talents and potentials does not indicate that the schools "implant" external knowledge in students, but rather that they draw the knowledge from human beings on the basis of the experience that is close to them and thus their own. School's creativity is therefore most visible in the fact that it allows an individual to be what he or she could be the best at and encourages him or her in this direction.

Before focusing on the actual teaching practice in a Catholic kindergarten, i.e. in early childhood education, we should briefly consider some of the challenges of holistic pedagogy.

\section{The Challenges of Holistic Pedagogy}

The interconnection of holistic pedagogy principles and Catholic schools' vision is not a given. It can be observed that the challenges of Catholic schools in the $21^{\text {st }}$ century ${ }^{10}$ are diverse. We will further focus on one of the most noteworthy challenges: integral education.

\footnotetext{
${ }^{9}$ Congregation for Catholic Education, Educating Today and Tomorrow: A Renewing Passion (Instrumentum laboris), available online: http://www.vatican.va/roman_curia/congregations/ ccatheduc/documents/rc_con_ccatheduc_doc_20140407_educare-oggi-e-domani_en.html (12 July 2016). Cf. Slovenian translation in: Marko WEILGUNY, Tadej RIFEL (ed.), Katoliško šolstvo pred izzivi časov, Collection: Katoliško šolstvo 1, Ljubljana, Inštitut za raziskovanje in evalvacijo šolstva 2014, 67-68.

${ }^{10}$ See Katoliško šolstvo pred izzivi časov, 71-85.
} 
Education should not be considered only from the functionalist point of view, where it is subordinated to the rationale of market economy and labour market needs. This technocratic and economic rationale should not be underestimated, as it is necessary to recognise the seriousness of youth unemployment. Nevertheless, the rationale of developing a multiplicity of skills that enrich students as integral persons is central to integral education. These skills include creativity, imagination, responsibility, justice, and compassion.

The second challenge is the risk of meritocracy, where the efforts and knowledge are only measured by the ultimate success. "/T/he pursuit of quality and excellence is indeed important, but we should never forget that students have very specific needs: they are often going through difficult circumstances, and deserve a pedagogical attention that takes their needs into account." ${ }^{11}$ In this context, the greatest challenge is to encourage teachers to be adequately prepared for such integral education.

Today, the majority of developed countries places particular emphasis on skill development within education. The purpose is not only to convey knowledge, but also the skills that would enable students to use the knowledge in everyday life. It is an attempt to establish a bond between school and life. The aim is not the mere acquisition of knowledge or abilities, but the development of the entire person. It is therefore not enough to enhance the skills related to usefulness, but also those that help individuals live alongside others and promote their personal growth. "These are reflective skills, for instance, by which we are responsible for our actions, or intercultural, decision-making, citizenship skills, that are becoming increasingly important in our globalized world and affect us directly, as is the case with skills related to consciousness, critical thinking and creative and transforming action. ${ }^{.12}$

The three main challenges of integral education vary in intensity at different education levels. They will be discussed below, together with the aspects of holistic pedagogy in early childhood education.

\section{Implementation of the Principles of Holistic Pedagogy in the Good Shepherd Kindergarten}

The Good Shepherd Kindergarten was founded in 2014 as one of the units of St. Stanislav's Institution in Ljubljana. It includes five units of children belonging to the younger and older age groups. Even before the selection of professional staff, the aim was to create a kindergarten environment that would function according to the principles of holistic pedagogy. This idea was thus

\footnotetext{
${ }^{11}$ Katoliško šolstvo pred izzivi časov, 76.

${ }^{12}$ Katoliško šolstvo pred izzivi časov, 77.
} 
crucial from the very beginning, when selecting the staff, naming the playrooms, setting up the annual activity plan, and identifying kindergarten's mission and vision. Below we will briefly describe the decisions, choices and activities resulting from the vision of holistic pedagogy.

\subsection{Selecting the Professional Staff}

One of the most significant tasks of preschool teachers is to create an emotional group atmosphere, thus providing children with a pleasant, accepting and stimulating environment. A child who feels save will have the courage to take risks, to explore, and to discover. Preschool teachers certainly have a feeling for working with children, as well as the ability to put themselves into their shoes and to show them kindness, gentleness, and creative spirit. However, all the above has to be supported by appropriate education and experience. The added value of kindergarten staff lies in its additional professional qualifications. Indeed, there is a wide range of different education profiles: Slovene teacher, PE teacher, primary school teacher, art teacher, musicologist, art historian, librarian, theologian, and biologist. All the employees cooperate closely and complement each other, creating an optimal environment for children to discover and develop their talents. In order to strengthen a common spirit, the kindergarten organises monthly planning sessions, collaborative projects, knowledge-sharing activities, and social gatherings. Teachers therefore carry out different activities for all kindergarten students: the art teacher is responsible for creative workshops, the musicologist for music workshops, the PE teacher for physical activities, the librarian for fairy-tale workshops, etc. All this considerably enriches everyday life in the kindergarten.

\subsection{Space as a Creative Environment}

The kindergarten is situated in a new modern building, offering children a variety of opportunities to develop their entire personality through modern architecture and large open playrooms equipped with the latest teaching materials and full of light and sun. Following the direction of the kindergarten, corridors and rooms are equipped with media players, allowing children to listen and to develop a sense of classical music. What is more, a special area is dedicated to the kindergarten library in order to establish early contact with the book, while the gym is equipped with mirrors, allowing children to observe their movement and dance steps. Every playroom includes an open panoramic wall and an exit to a covered terrace, thus putting children in as direct contact with nature as possible. A large playground is shaded by trees, which brings a sense of naturalness. Finally, a covered pavilion and terrace enable children to 
take part in outdoor activities even in bad weather. On the kindergarten playground, the so-called camping days are organised meaning that children along with their teachers spend two days outdoors and sleep in tents. They become familiar with forest, meadows, animals, weather.

One of the most interesting features of the Good Shepherd kindergarten is an outdoor classroom, where children, in the shade of trees, have an opportunity to use wooden playground equipment, take care of small gardens and thus follow how plants grow. Next to the outdoor classroom, there is a wooden fence, where children can observe and feed two sheep. The outdoor classroom is often a place where different activities that draw children closer to the nature are carried out. In this way, children gain new knowledge and interests and this is a very important aspect of holistic pedagogy.

Both children and employees are therefore truly inspired by their aesthetic and functional working environment.

\subsection{Cooperation with the Environment}

The kindergarten cooperates with all the units of St. Stanislav's Institution (primary school, gymnasium, both student dormitories, and music school). The students of the Alojzij Šuštar Primary School organise theatre performances and art workshops for kindergarten students, while the latter can participate in first-year primary school lessons. They can also make daily visits to the primary school library and attend fairy-tale workshops prepared by the librarian. There is also a large library in the Diocesan Classical Gymnasium, where the librarian organises fairy-tale workshops and library visits for kindergarten students, while individual professors occasionally carry out different activities (e.g. a Slovene professor presented the books she wrote, a physics professor presented stargazing, etc.). In the morning, gymnasium and university students volunteer in the kindergarten, participating in kindergarten activities, playing with children, producing teaching materials, etc. The music school organises the presentations of musical instruments and professional musicians' work, while its students perform at the openings of kindergarten art exhibitions. Moreover, the kindergarten cooperates with the joint services operating within the institution. It often invites maintainers to help children build bird boxes, slide stairs or wooden boats. The presentation of the kindergarten's water distribution system was also very interesting; children learned where water comes from and what is needed to obtain it. Finally, the kindergarten is integrated into the wider environment, including occasional visits from a dental assistant who works at the nearby health centre, firefighters, police officers, and soldiers.

The headteachers of Catholic kindergartens (there are 20 of them in Slovenia) attend work meetings three times a year, planning the events that are common to all Catholic kindergartens. They thus build a community that strives 
to live and work by the values of respect, integrity, honesty, openness, and tolerance. This year, all Catholic kindergartens and other Catholic educational institutions set up a joint website, ${ }^{13}$ aimed at providing the exchange of teaching materials, scientific articles, employees' reflections, and good practices.

The administration of the Good Shepherd Kindergarten strives for an ongoing evaluation and feedback from parents. At the parent's council, representatives of all groups present parents' opinions, suggestions and ideas. In addition to the regular parent's council meetings, a special evaluation of the Good Shepherd Kindergarten was carried out by the Institute for Education Research and Development in the 2015/16 year. Both parents and employees completed a questionnaire and an external evaluator evaluated the kindergarten as well.

\section{Various Activities to Stimulate Children's Abilities and Creativity}

The programme implemented in public and most private kindergartens is Kurikulum za vrtce (Kindergarten Curriculum) ${ }^{14}$, which has been gradually introduced in the area since 1999. In the first part of the curriculum, kindergarten educational activities are defined by theoretical premises, objectives, and principles. The second part specifies different global objectives for the first and second age groups, as well as the objectives and examples of activities for specific areas (locomotion, language, arts, society, nature, and maths). "The national Kindergarten Curriculum has provided kindergartens and teachers with a higher degree of autonomy, while requiring highly-qualified staff in all the areas of activities." ${ }^{15}$ Since the objectives set for the individual areas of activities only constitute a framework for activity-planning, kindergartens and teachers are allowed to connect, upgrade and complement the proposed content. The Good Shepherd Kindergarten thus devotes special attention to fine arts, dance, locomotion, language (especially through early contact with the book), and spirituality. The latter is well integrated into the life of the kindergarten.

\subsection{Music Activities}

The greatest emphasis is placed on early contact with music, which is of immense importance for the holistic development of child's personality. "Listening, performing, and creating music does not only have an impact on musical

\footnotetext{
${ }^{13}$ See the above-mentioned website: http://solstvo.rkc.si/ (12 July 2016).

${ }^{14}$ Kurikulum za vrtce: predšolska vzgoja v vrtcih, Ljubljana, Ministrstvo za šolstvo in šport, Zavod Republike Slovenije za šolstvo, 2011.

${ }^{15}$ Načrtovanje glasbenih dejavnosti v zgodnjem obdobju otroštva, 74 .
} 
development, but also on the overall aesthetic, moral, physical, and intellectual development." ${ }^{\prime 16}$ When children arrive in the kindergarten in the morning, they can listen to the music written by different classical composers in the corridor. What is more, at the openings of art exhibitions and other events, they are visited by music school students who perform for them and present different musical instruments. Throughout the year, the younger children can attend an activity called "Musical Gatherings", where they learn about and play on the Orff instruments, get to know each other through singing and music games, get accustomed to the basic elements of singing, listen to classical music, and learn about different musical instruments and professional musicians' work. The programme includes the individual elements of Edgar Willems' method ${ }^{17}$ as well as the preparation and implementation of a musical fairy tale. The older children can attend an activity called "Let's Sing Along", where they learn about and play on the Orff instruments as well as accompany each other by them, get to know the basics of choral singing (correct posture, joint beginnings, loud/quiet singing, changing the tempo, following the conductor, expressing emotions, capturing different moods (interpretation), etc.), rehearse with professional conductors, and listen to classical music. The programme also includes the preparation and implementation of a musical fairy tale. Finally, children sing in the playrooms on a daily basis, accompanied by a variety of musical instruments.

\subsection{Art Activities}

The kindergarten cooperates with painters and art teachers, who stage art exhibitions in the kindergarten corridors. Children observe and comment on the works of art and learn by living with them on a daily basis. Exhibitors organise and carry out art workshops for all kindergarten students, who thus learn about clay characteristics and modelling, dye t-shirts, and use recycled materials to create their own works of art. The art teacher prepares a variety of creative workshops throughout the year, allowing children to use different materials and techniques.

\subsection{Physical Activities}

Physical activities are organised and conducted by the PE teacher. The older children attend free beginner's ski lessons in the kindergarten playground, where they can learn how to glide, climb up the hill in side steps, descend the

\footnotetext{
${ }^{16}$ Načrtovanje glasbenih dejavnosti v zgodnjem obdobju otroštva, 5.

${ }^{17}$ The method of introduction to music developed by Edgar Willems provides an intense and systematic approach to musical and broader aesthetic education in the early childhood. Children develop their musical skills and acquire the basic knowledge of music through guided play.
} 
slope, stem, stop, and turn. Every month, an obstacle course is set up in the kindergarten corridor, covered terrace or playground, allowing children to develop specific motor skills. Moreover, the older children can attend free rollerblading, cycling, and skating lessons. They can also participate in dancing activities, where they get to know children's and folk dances, counting-out rhymes, circle games, action songs, creative and expressive dancing, as well as learn how to make choreographies for different songs and compositions.

\subsection{Early Contact with the Book}

The availability of books in kindergartens is of paramount importance when it comes to literary education. Books should be within the reach of children and available whenever a child wants to read, flip through them or only study illustrations. Interestingly, PIRLS $2006^{18}$ showed that the reading environment, measured by the number of books and the number of children's books at home, had a considerable impact on children's reading achievements. Consequently, the Good Shepherd Kindergarten has a room converted into a library, where children can gather around beautiful and high-quality books. Named the "Fairy-Tale Room", it represents a world of fairy tales that wait for children on the shelves. The room is equipped with children's armchairs, table, chairs, and cushions. Children are strongly attracted by the welcoming atmosphere that creates a sense of a family living room. Every morning and every afternoon upon arrival and departure, children and their parents can stay in the room for a while and read children's literature. During the time spent in the kindergarten, children can always be in direct contact with the book. All books are entered in the Slovenian library database (COBISS) and can be borrowed. This year, the room was brightened up with the puppets made by our employees within the Lutke v vrtcu (Puppets in the Kindergarten) seminar. They can be used by all those who enter the "Fairy-Tale Room". Children can thus recreate individual stories: they can play a certain story using the puppets or make up a completely new story while interacting with other children.

In addition to fairy-tale workshops, i.e. "a form of literary education that gradually and systematically prepares and introduces children to the fairy-tale world and to education through books", ${ }^{19}$ pre-reading competences and skills are developed by several other activities: book backpack, Ciciuhec (reading together with parents), pre-school reading badge, and visits to various libraries. The Good Shepherd Kindergarten devotes special attention to early contact

\footnotetext{
${ }^{18}$ Poučevanje branja v Evropi: okoliščine, politike in prakse, Ljubljana, Ministrstvo za šolstvo in šport, 2011, 117.

${ }^{19}$ Tilka JAMNIK, Knjižna vzgoja otrok od predbralnega obdobja do 9. leta starosti, Ljubljana, Zavod Republike Slovenije za šolstvo in šport, 1994, 12.
} 
with the book and believes that the latter plays a key role in helping children grow into good readers.

\subsection{Spirituality in Kindergarten}

Spirituality is one of the most important emphases of the Good Shepherd Kindergarten. We develop and encourage it in different ways. The Catechesis of the Good Shepherd is carried out and adjusted for children aged between three to six years. It is carried out by a qualified teacher in a special room called atrium. The room is equipped with various materials that help children get to know Bible stories and liturgy. In addition to the catechesis, the Bible workshops are also organized. They are aimed at bringing religious truths, liturgy and Catholic holidays closer to children and include the narration of the Bible stories, prayers, games, dancing, singing, and art activities. One of the biggest advantages in establishing contacts with spirituality is the presence of a priest that is also part of the staff. He joins each of the groups on a weekly basis and takes part in their daily activities. He also celebrates masses in the Good Shepherd Chapel. He is a model to children and other employees. A special attention is also given to the preparation and celebration of Catholic holidays, e.g. Christmas, Easter and others.

\section{An Example of Good Practice - "Day of Activities"}

The older children are divided into heterogeneous groups (3-6 years). However, once a week, the children of the same age mingle with each other. This day is called the "Day of Activities". In their original groups, younger and older children learn to help each other, while the activities carried out by the children of the same age help them further develop individual skills, such as locomotion, dance, and musical creativity. Every Wednesday between 9 and 11 a.m., children are divided into the groups of the same age by playing the "travelling train" game, which gathers the children of the same age. The older ones take part in the "Let's Sing Along" activity, dancing, and the "Catechesis of the Good Shepherd", ${ }^{20}$ while the younger ones participate in music activities, "Musical Gatherings", and the "Bible Workshop"21. The younger children are

\footnotetext{
${ }^{20}$ The "Catechesis of the Good Shepherd" is a preaching approach to religious education that respects children's religious abilities. The main pillars of the catechesis are its firm theological basis (the Bible and the liturgy as direct sources of divine revelation) and its solid pedagogical basis (the Montessori approach that respects children's personality and abilities).

${ }^{21}$ The "Bible Workshop" is aimed at bringing religious truths, liturgy and Catholic holidays closer to children and includes the narration of the Bible stories, prayers, games, dancing, singing, and art activities.
} 
also free to play as they want. The shelves contain educational toys that help them develop the competences and skills typical of their age group.

All activities are conducted by those teachers and their assistants who have the necessary professional and university education or have attended seminars and trainings in individual fields (music, dance, training programme for Willems' teachers, "Bible Workshop", "Catechesis of the Good Shepherd", etc.). The implementation of such activities requires close cooperation and engagement of all employees. Children cooperate with all kindergarten teachers, which contributes to a sense of a community where everyone knows each other well and works together.

The "Day of Activities" engages all kindergarten students and represents an example of a stimulating environment for discovering and developing individual talents in the areas of locomotion, dance, and musical creativity. By involving all children in the described activities, which usually take place in the afternoon and are payable in other kindergartens, the possibility of excluding individual children who would not be able to participate in such activities due to the social status of their families is eliminated. Thus, they all have the opportunity to develop their full potential in an environment that supports the cultivation of their skills and talents.

\section{Conclusion}

We believe that holistic pedagogy is not a privilege of Catholic schools. It is a tool that can be used by any school to address and clarify the current educational issues within a relatively well-established system. Therefore, the challenges of holistic pedagogy are always placed in the context of individual schools and their specific situation. The challenges that apply to Catholic schools do not fully apply to secular or other schools that follow different educational principles. Nevertheless, the question should be repeatedly raised to what extent certain principles contribute to the enrichment of schools and to the common good. The example of early childhood education showed how an environment of holistic pedagogy could enable children to learn and experience many valuable lessons in the earliest period of their lives. 


$$
\text { Špela Avšič** }
$$

Holistička pedagogija i predškolski odgoj. Vrtić Dobroga pastira u Zavodu sv. Stanislava u Ljubljani

\section{Sažetak}

U prvom dijelu članka predstavljene su osnovne značajke holističke pedagogije. Najprije su opisana načela i temeljno ishodište koje u središte postavlja čovjeka kao osobu. Time su postavljeni okviri teorije za daljnju tematizaciju pedagoške prakse u predškolskom odgoju. Autori se u nastavku oslanjaju na iskustvo holističke pedagogije na području katoličkoga školstva. Postavljena su ključna težišta koja isprepliću novosti obrazovnog okruženja i vrijednosti katoličke škole. Posebice je istaknut stvaralački aspekt. U drugom dijelu autori opisuju pedagoška načela na primjeru Vrtića Dobroga pastira koji djeluje u Zavodu sv. Stanislava u Ljubljani. Katolički vrtić potvrđuje i razvija holističke pristupe na mnogim područjima u odgoju djece toga uzrasta.

Ključne riječi: holistička pedagogija, predškolski odgoj, katoličko školstvo, kreativnost, pedagoška praksa.

(na hrv. prev. Ana Cvijanović)

\footnotetext{
* Špela Avšič, Ravnateljica Vrtića Dobroga pastira, Zavod sv. Stanislava, Štula 23, 1210 Ljubljana Šntvid; e-mail: spela.avsic@stanislav.si.

** Dr. sc. Tadej Rifel, asistent, neovisni znanstvenik na Institutu za istraživanje i procjenu školstva, Zavod sv. Stanislava, Štula 23, 1210 Ljubljana Šentvid; e-mail: tadej.rifel@stanislav.si.
} 